\title{
Transfer of Regional Government Stock in PT. Indotan Lombok Barat Bankit through Sircular Shareholder General Meeting
}

\author{
Lalu Athfal Fikry; Salim Hs; Kurniawan \\ Postgraduate students, Faculty of Law, Mataram University, Indonesia \\ http://dx.doi.org/10.18415/ijmmu.v6i1.845
}

\begin{abstract}
This study aims to analyze the transition of shares of Regional Government through Circular shareholders general meetings. Related to this matter, the regulation of share transfer through the Circular general shareholders meeting. This research is a type of normative research, with the approach used is a legal approach and a conceptual approach. Circular transfer of shares is clearly stipulated in article 91 of Law Number 40 of 2007 concerning Limited Liability Companies. That a decision outside the general meeting of shareholders approved by all shareholders is a "binding" decision. That is, the decision has the same legal force as the decisions of the general meeting of shareholders carried out physically and conventionally. Then the next arrangement is regulated in article 14 of the Cooperation Agreement between Indotan Lombok, Pte. Ltd., PT Puri Permata Mega, and West Lombok Regency Government Based on Notarial deed Number AHU-AH.O1.10-09847. If in the analysis of the agreement theory, this agreement has fulfilled the legal requirements of an agreement. The implementation was carried out with evidence that PT Puri Permata Mega had transferred its shares to PT Indotan Lombok, Pte. Ltd. This is evidenced by the agreement of Indotan Lombok, Pte, Ltd and the West Lombok Regency Government.
\end{abstract}

Keywords: Transfer of Shares; Circular Shareholders General Meeting

\section{Introduction}

Limited liability company is the most preferred form of economic activity at this time, besides because of its limited liability it also makes it easy for the owner (Shareholder) to transfer his company to everyone by selling all of the shares he owns to the company ${ }^{1}$. In carrying out its business, it is made to Profit Oriented. For the State, the existence of the company is very profitable, because of its contribution as a source of state revenue both from the tax sector and channeling labor.

According to Law No. 40 of 2007 concerning Limited Liability Company is a legal entity which is a capital alliance, established under an agreement and conducting business activities with authorized

\footnotetext{
${ }^{1}$ Ahmad Yani dan Gunawan Widjaja, Seri Hukum Bisnis PerseroanTerbatas: Cetakan I, Jakarta, Raja grafindo Persada, 2000, hlm. 1.
} 
capital which is entirely divided into shares. Limited Company Organ is a General Meeting of Shareholders, Directors, and Board of Commissioners.

A limited company has 3 (three) important organs, the three organs are general meeting of shareholders, directors and board of commissioners. These organs have their respective functions and duties which have an organic and functional relationship between one organ and another in accordance with the provisions of the law on limited liability companies and the articles of association of the company ${ }^{2}$.

Limited Liability Company as a capital partnership, the Limited Liability Company consists of capital which is fully divided into shares. The founders of the Limited Liability Company are obliged to take the share of capital in the form of shares and they get proof of the share certificate as a form of capital participation. The responsibility of the shareholders is limited to the shares that are included in the Limited Liability Company.

Article 1 number 4 of Law Number 40 of 2007 concerning Limited Liability Companies which states that the General Meeting of Shareholders is the Organ of the Company which has authority not given to the Board of Directors or the Board of Commissioners within the limits specified in this Law and /or Articles of Association. The General Meeting of Shareholders is a forum for the shareholders of the company, and a means for him to channel his aspirations for his interests within the company ${ }^{3}$.

As a decision maker, the General Meeting of Shareholders has a big responsibility in the steps taken by a Limited Company. Each decision determines how the progress and continuity of business activities of the next Limited Company. But in many Limited Companies, shareholders only hand over their business activities to directors and board of commissioners. Even though it is important for shareholders to know the condition and development of a Limited Company in making decisions made through the General Meeting of Shareholders ${ }^{4}$.

The General Meeting of Shareholders decides on important matters regarding the policy of a company that are not limited to the appointment or dismissal of Commissioners and Directors only. The authority of the General Meeting of Shareholders is realized in the form of the number of votes issued at each meeting. Voting rights at the General Meeting of Shareholders can be used for various purposes and objectives, such as the plan to sell assets and provide debt guarantees, approve the financial statements submitted by the board of directors, accountability of the Board of Directors, planned merger, consolidation, takeover and plan to dissolve the company ${ }^{5}$.

Organ that runs a Limited Liability Company and acts as a manager in operational activities is called the Board of Directors. Authority possessed by the Board of Directors according to Article 1 Jo Article 92 paragraph 1 of the 2007 Limited Liability Company Law "The Board of Directors is the Company's organ that is authorized and responsible for managing the company in the interests of the

2 Wardani Rizkianti, Akte Otentik Rapat Umum Pemegang Saham (RUPS) Melalui Media Telekonferensi (Mekanisme Pembuatan dan Kekuatan Pembuktiannya), Jurnal Yuridis, Vol. 3, No. 1, hlm. 2 , (2016), di akses dari https://ejournal.upnvj.ac.id/index.php/Yuridis/article/viewFile/172/144, tanggal 19 April 2019.

${ }^{3}$ David, Legalitas Akte Notaris Rapat Umum Pemegang Saham Melalui Media Telekonferensi, Jurnal Ilmu Hukum, vol. 13, No. 1, hlm. 3, (2013), diakses dari http://e-journal.uajy.ac.id/5084/1/Jurnal\%20DAVID.pdf, tanggal 19 April 2019.

${ }^{4}$ Pahlefi, Eksistensi RUPS sebagai Organ Perseroan Terkait Dengan Pasal 91 Undang-Undang Perseroan Terbatas, Jurnal Ilmu Hukum, vol. 7, No. 2, hlm. 3, (2016), diakses dari http://repository.unja.ac.id/622/1/8.\%20Pahlefi.pdf,tanggal 19 April 2019.

${ }^{5}$ Kurniawan, Hukum dan Hukum Perusahaan Karakteristik Badan Usaha Berbadan Tidak Berbadan Hukum Di Indonesia: Cetakan I, Jakarta, PT Raja Grafindo, 2014. hlm. 66. 
company, in accordance with the company's goals and objectives and representing the company both inside and outside the Court in accordance with the provisions of the articles of association. "It can be concluded that the Board of Directors has two functions, namely management and function of representation ${ }^{6}$.

Circular decision making is carried out by circulating the proposed decision and must be approved by all shareholders. Circular decision-making on publicly listed companies will experience obstacles in fulfilling the implementation procedures, given the large number of shareholders in public companies. Arrangements regarding circular resolution can be applied to closed portions and cannot be applied to open proportions. Circular decision making is carried out by circulating the proposal of a decision, without a meeting as required by law. The proposal for the decision must be approved by all shareholders, while the decision at the annual General Meeting of Shareholders is valid if it has been approved by half of the number of votes issued. The discussion of the Annual General Meeting of Shareholders is clear about decision making up to its validity but there has been no further discussion regarding decision making by means of circular resolution in the law, so the authors are interested in studying more about circular resolution ${ }^{7}$.

In Article 334 paragraph 1 of Law No. 23 of 2014 concerning Regional Government Regional Owned Enterprises are those whose capital is owned by one Region and is not divided into Shares. In the provisions of the Article above it states that the Regional-Owned Enterprise is owned by one Region and is not divided into Shares, but the implementation of Regional Owned Enterprises provides space for parties to be able to invest their Shares, so that Regional Owned Enterprises no longer have controlled Capital by the Regional Owned Enterprise itself. In West Lombok there was cooperation between the Regional Government and Indotan Lombok PTE LTD, PT Puri Permata Mega formed PT Indotan Lombok Barat Bangkit (ILBB). In the cooperation agreement, Article 14 concerning the transfer of paragraphs $2 \mathrm{a}$ and $\mathrm{b}$ governs the process of transferring shares. Before transferring the shares, the General Meeting of Shareholders and government approval is needed, but in reality the process of transfer of shares carried out by PT Indotan Lombok Barat Bangkit is not in accordance with the cooperation agreement. Circular Shareholders General Meeting?

\section{Pembahasan}

\subsection{Arrangement of share transfer through Circular Shareholders General Meeting}

Limited liability companies as subjects of artificial law cannot possibly act alone. This condition is different from humans, who naturally have been given equipment to carry out actions in their life activities because limited liability companies are artificial subjects needed by people who have the will to run the company in accordance with the purpose and objectives of the company's establishment. The people who will run and manage the Limited Liability Company Law are referred to as company organs ${ }^{8}$.

In a limited liability company there are 3 limited state equipment organs (Article 1 paragraph 2 of Law Number 40 Year 2007 concerning Limited Liability Companies), namely general meeting of shareholders, directors, and commissioners. So what is meant by a limited company organ is a person who is a manager of a limited liability company. First of all, I need to say that in accordance with Article 1 paragraph (4) of Law No. 40 of 2007 concerning Limited Liability Companies, the General Meeting of

\footnotetext{
${ }^{6}$ Ridwan Khairandy, Hukum Perseroan Terbatas: Cetakan I,Yogyakarta,FH UII Press, 2014. hlm. 256.

${ }^{7}$ Livia Cenggana, Pengambilan Keputusan Dengan Metode Circural Resolutian Dalam Perseroan Terbatas Sebagai

Badan Hukum,Jurnal Hukum, vol. 16 No 1, hlm. 9, (2016), Diakses dari http://ejournal.uajy.ac.id/11578/1/JURNAL\%20HK11204.pdf, tanggal 20 April 2019.

${ }^{8}$ Zaeni Asyhadi dan Budi Sutrisno, Hukum Perusahaan dan kepailitan: Jakarta: Erlangga, 2013, hlm. 92.
} 
Shareholders is the Company's Organ which has authority not given to the Board of Directors or Board of Commissioners within the limits specified in the Law Limited Liability Company and/or the Company's articles of association.

The General Meeting of Shareholders decides important matters concerning the policy of a company that are not limited to the approval or dismissal of commissioners and directors only. The authority of the General Meeting of Shareholders is realized in the form of the number of votes issued at each meeting. Voting rights at the General Meeting of Shareholders can be used for various purposes and objectives, such as the plan to sell assets and provide debt guarantees, approve the financial statements submitted by the directors, accountability of the directors, planned merger, consolidation, expropriation and plan to dissolve the company. The General Meeting of Shareholders consists of the Annual General Meeting of Shareholders and other General Meeting of Shareholders. The annual General Meeting of Shareholders must be held no later than 6 months after the financial year ends. In the annual General Meeting of Shareholders, all documents from the Company's annual report must be submitted which include:

a. Financial statements consisting of at least the balance sheet at the end of the recent financial year in comparison with the previous financial year, income statement of the relevant financial year, cash flow statement, and report on changes in equity, and notes to the financial statements;

b. Report on the activities of the Company;

Meanwhile, other General Shareholders Meetings can be held at any time based on the needs for the benefit of the Company. In practice, there is a known Extraordinary General Meeting of Shareholders held anytime based on needs 9 .

Article 1 number 4 of the Limited Liability Company Law No. 40 of 2007, explaining what is meant by a General Meeting of Shareholders is a company organ that has authority not given to the Board of Directors or the Board of Commissioners within the limits specified in this Law and/or the Articles of Association. The General Meeting of Shareholders decides important matters concerning the policy of a company that are not limited to the approval or dismissal of commissioners and directors only. The authority of the General Meeting of Shareholders is realized in the form of the number of votes issued at each meeting. Voting rights at the General Meeting of Shareholders can be used for various purposes and objectives, such as the plan to sell assets and provide debt guarantees, approve the financial statements submitted by the directors, accountability of the directors, planned merger, consolidation, expropriation and plan to dissolve the company. The authority of the general meeting of shareholders according to Law Number 40 of 2007 concerning Limited Liability Companies Number 40 of 2007.

Law Number 40 of 2007 concerning Limited Liability, regulates several types of general meeting of shareholders, namely:

a. general meeting of ordinary shareholders (annual), which must be held at least once in each financial year of the company.

b. extraordinary general meeting of shareholders, which is only held specifically at the request of directors, commissioners, and shareholders representing at least $10 \%$ of the total shares that have been legally issued by the company.

\footnotetext{
${ }^{9}$ Azizah, Hukum Perseroan Terbatas: Malang,Intimedia,2015. Hlm. 132-133.
} 
Article 40 The Commercial Law Act describes the limitation of responsibility of shareholders. This means that all risk of loss is fully borne by a collection of capital originating from the founders and/or shareholders who are separated from their assets and are the assets of a Limited Liability Company not to the assets of its shareholders. The provisions of Article 40 of the Commercial Law Law are reaffirmed in Article 3 of Act Number 1 of 1995 concerning Limited Liability Companies and the provisions of Article 3 of Law Number 40 of 2007 concerning Limited Liability Companies.

The provisions of Article 3 of the Limited Liability Company Law, stated that if in the future legal responsibility arises that must be fulfilled by a Limited Liability Company, then the liability is solely borne by the assets collected in the company. In other words, the Limited Liability Company legally has its own responsibility, even though the property comes from the companies or shareholders, the assets are completely separated from the assets of each company or shareholder ${ }^{10}$.

The General Meeting of Shareholders can also be done through electronic media. The provisions are regulated in Article 77 of Law Number 40 of 2007 concerning Limited Liability Companies ${ }^{11}$. The arrangement of the General Meeting of Shareholders through electronic media was not previously regulated in Law Number 1 of 1995, only when Law Number 40 of 2007 concerning Limited Liability Companies was regulated by the way in which the General Meeting of Shareholders was held through electronic media. In order for the General Meeting of Shareholders through electronic media to be legitimate and justifiable, all participants of the General Meeting of Shareholders must see each other and hear directly and participate in the meeting. Save the author, decision making at the General Meeting of Shareholders through the media of teleconferencing or video conferencing can also be conducted by a board of directors meeting, provided that it is determined firmly in the articles of association of the company ${ }^{12}$.

Based on this provision, there are differences in the making and signing of minutes of the General Meeting of Shareholders through electronic media with minutes of General Meeting of Shareholders through electronic media with minutes of conventional conventional Shareholders' Meetings.

The signing of the minutes of the conventional General Meeting of Shareholders according to Article 90 paragraph (1) must only be signed by:

a. Chair of the meeting, and

b. At least one shareholder appointed from and by the participants of the General Meeting of Shareholders.

So the minutes of the General Meeting of Shareholders conducted physically and conventionally, are not signed by all participants of the General Meeting of Shareholders. Instead the minutes of the General Meeting of Shareholders conducted through electronic media must be signed by all shareholders. Thus, in addition to its contents, it must be approved by all participants of the General Meeting of Shareholders, must also be signed by all participants of the General Meeting of Shareholders.

Furthermore, what is meant by "approved and signed" according to the explanation of Article 77 paragraph (4) is approved and signed "physically" or "electronically". In other words, it may be approved and signed physically or can also be electronically by all meeting participants ${ }^{13}$.

${ }^{10}$ Kurniawan. Hukum Perusahaan: Yogyakarta, Genta Publishing, 2014, hlm. 66-70.

${ }^{11}$ Azizah, ibid, hlm. 131.

${ }^{12}$ Azizah, ibid, hlm. 132.

${ }^{13}$ M. Yahya Harahap, Hukum Perseroan Terbatas: Jakarta,Sinar Grafika, 2009. hlm. 314. 
Under Article 91 the Law on Limited Liability Companies allows shareholders to make "binding" decisions outside the General Meeting of Shareholders. In the explanation of article 91 which states, what is meant by "decision making outside the General Meeting of Shareholders" in practice is known as "circulation resolution". It means that the decision is taken by the shareholders not in the formal General Meeting of Shareholders. preceded by submission of summons. So, it is not done and there is no physical General Meeting of Shareholders.

Whereas the mechanism or method of decision making outside the physical General Meeting of Shareholders is carried out by:

a. Sending in writing the proposal that will be decided to all shareholders, and

b. The proposal, agreed in writing by all shareholders.

Approval from all shareholders is an absolute requirement for the validity of a decision outside the General Meeting of Shareholders. No one shareholder may disagree. If something like that happens, the circulation resolution will be illegal (onwettig, unlawful) ${ }^{14}$.

In Article 91 of the Limited Liability Company Law, the shareholders can also make binding decisions outside the General Meeting of Shareholders on the condition that the shareholders with voting rights approve in writing by signing the proposal in question. Explanation of Article 91 of the Limited Liability Company Law states that what is meant by "decision making outside the General Meeting of Shareholders" in practice is known as a proposed decision that is circulated (circular resolution). Added by the explanation of the article that the decision making was carried out without a physical General Meeting of Shareholders, the decision was taken by sending a written proposal that would be decided to all shareholders and the proposal was agreed in writing by all shareholders and the proposal was approved written by all shareholders. Finally, the explanation of the article states that what is meant by "binding decision" is a decision that has the same legal force as the decision of the General Meeting of Shareholders.

The General Meeting of Shareholders by means of circular resolution or circular letter is not a form of separate General Meeting of Shareholders such as the Annual General Meeting of Shareholders and the extraordinary General Meeting of Shareholders. This is only a way to carry out the General Meeting of Shareholders. This method can be applied both to the implementation of the annual General Meeting of Shareholders or the Extraordinary General Meeting of Shareholders ${ }^{15}$.

Therefore, the transfer of circular shares is clearly stipulated in Article 91 in conjunction with Article 91 of Law 40 of 2007 concerning Limited Liability Companies. However, the author will see the implementation of this circular share transfer in a cooperation agreement between Indotan Lombok, Pte. Ltd., PT Puri Permata Mega, and the West Lombok District Government regarding a joint venture in the mining business.

\footnotetext{
${ }^{14}$ M. Yahya Harahap. Ibid, Hlm. 341.

${ }^{15}$ Ridwan Khairandy, Perseroan Terbatas: Doktrin, Peraturan Perundang-Undangan, dan Yurispruden: Yogyakarta, Total Media Yogyakarta, 2009. hlm. 202.
} 


\subsection{Analysis of the Cooperation Agreement between Indotan Lombok, Pte. Ltd., PT Puri Permata Mega, and West Lombok Regency Government Based on Notarial deed Number AHU-AH.O1.10- 09847.}

Cooperation agreement between Indotan Lombok PTE. LTD with PT Puri Permata Mega and the West Lombok District Government regarding the Mining Business Joint Venture. Indotan, PT Puri Permata Mega and Lombok Barat District Government, then collectively called the parties and individually called parties.

The parties wished to form a joint venture business and for that matter. The parties have established a limited liability company under the name PT Indotan Lombok Barat Bangkit (ILBB) based on the establishment deed no. 263 November 30, 2010, made before Arry Supratno, SH, a notary in Jakarta where PT Indotan Lombok Barat Bangkit (ILBB) will apply for an exploration mining business permit without going through a tender process, and if it is deemed commercially viable, it will carry out development and will carry out production operations on gold metal minerals and mineral followers in the area referred to in the exploration Mining Business License. The parties agreed that the shareholding of the Government of West Lombok district in PT Indotan Lombok Barat Bangkit would not be diluted to less than $10 \%$ of the total shares issued by PT Indotan Lombok Barat Bangkit in accordance with the terms of this agreement.

The relationship of the parties as stipulated in Article 18 as follows:

Paragraph 1 the rights and interests and responsibilities and obligations of each party according to this agreement are individual and separate and not joint or collective and each party is responsible for and only on its own obligations the parties do not intend to form a partnership/partnership, and this agreement cannot be interpreted in such a way that it causes the parties or one of them to be responsible as partners or partners.

Whereas paragraph 2 affirms unless clearly stated otherwise in this agreement, there is no one thing in this agreement which can be interpreted as one party being the legal power or representative of one of the other parties for any purpose no party has the right or the authority to in any way carry out or make an agreement in any form or to provide a guarantee or statement, either openly or implicitly, on behalf of or on behalf of another party.

The obligation of the confidentiality of information referred to in Article 19 paragraph 2 will continue to bind the parties and everyone who becomes a party to this agreement after he is no longer a party to this agreement or if this agreement ends. At the end of this agreement, or if one of the parties is no longer a shareholder in PT Indotan Lombok Barat Bangkit, each party, or party, whichever is appropriate, must immediately submit to the other party as appropriate all written documents, including copies, regarding or related to the confidential information of the other party, no longer using these documents, and making reasonable efforts to ensure that these documents are no longer used by employees, agents or contractors of the submitting party.

Based on Article 8 paragraph 1, the first establishment of PT Indotan Lombok Barat Bangkit was that the relationship between the parties relating to PT Indotan Lombok Barat Bangkit was regulated in this agreement and the articles of association. Second, if there is a conflict or discrepancy between the articles of association and the agreement, then this agreement is considered as an agreement and the applicable document between the parties regarding the matter except if required otherwise by the applicable laws and regulations. The parties must immediately take the necessary steps to improve the articles of association so that they are in accordance with this agreement as long as they are permitted by applicable laws and regulations (Article 8 paragraph 2) Third In connection with article 8 paragraph (1) 
and deed of establishment, the parties acknowledge and state that, the articles of association as contained in the deed of establishment, will be amended so that the articles of association reflect the provisions of this agreement. The parties agree that changes to the articles of association will be made no later than 7 days from the date of this agreement unless extended based on the agreement of the parties (Article 8 paragraph 3) Fourth, when PT Indotan Lombok Barat Bangkit was established prior to the approval of the Deed of Establishment: ( a) Every mention of the term shareholder applies to the parties, and every mention of the term shareholders meeting means the meeting of the parties as founders; and (b) All mentions of the terms of the Board of Directors and its members in this agreement apply to persons appointed in the Deed of Establishment as the Board of Directors and its members, who will act as administrators, and collectively as the management group in handling all PT Indotan Lombok affairs Barat Bangkit has the same function as the Board of Directors and its members according to the Deed of Establishment (Article 8 paragraph 4) Fifth, As soon as the Deed of Establishment is made, the Board of Directors will endeavor to obtain a license and approval registration license and will register with the tax office and officials other authorities as required by applicable legislation or whatever is needed by PT Indotan Lombok Barat Bangkit to carry out its business in accordance with its founding intent as stipulated in the Deed of Establishment and this agreement (Article 8 paragraph 5) Sixth, Immediately after the Establishment Deed is approved by the Ministry of Law and Human Rights, P T Indotan Lombok Barat Bangkit will instruct the Board of Directors to complete all registrations and publications, obtain all permits, licenses and approvals and carry out all actions ordered by the laws and regulations applicable or required by PT Indotan Lombok Barat Bangkit in carrying out its business in accordance with the purpose and objectives set out in the Deed of Establishment, including but not limited to making and maintaining a register of shareholders of PT Indotan Lombok Barat Bangkit (Article 8 paragraph 6).

To prevent one party, if he is indeed entitled according to the articles of association to sell his shares in PT Indotan Lombok Barat Bangkit to the buyer of another party, to disclose to the other party buyers the potential confidential information related to PT Indotan Lombok Barat Revived and its operation had previously revealed The information is that the party intending to sell the shares has received written approval from the buyer of another party not to disclose that information to another person, and only uses that information to evaluate whether or not to buy shares offered for sale.

Exemption from sanctions is regulated in article 20 of this agreement, namely: If a party violates the provisions of this agreement, the other party may at its own discretion (and, both according to the terms and conditions imposed) render the party who violates the responsibility and sanctions that should arise from these violations, without prejudice to the other party's right to take action at any time for further violations of the provisions of this agreement that are not declared free of sanctions.

The applicable jurisdiction and law are regulated in Article 24, namely: This agreement must be interpreted and interpreted in accordance with the laws of the Republic of Indonesia. The parties understand the possibility of inadequate monetary damages in resolving disputes that can be arbitrated. Therefore, the parties hereby declare that they agree to the inclusion and implementation of a decision that provides fulfillment of contractual obligations of all provisions in this agreement, including the payment of monetary losses.

According to the author, the secular transfer of shares is clearly stipulated in Article 91 and is also explained in the explanation of Law 40 of 2007 concerning Limited Liability Companies. Then the next arrangement is regulated in Article 14 of the Cooperation Agreement between PT Indotan Lombok, Pte. Ltd., PT Puri Permata Mega, and West Lombok Regency Government Based on Notarial deed Number AHU-AH.O1.10-09847. If in the analysis of the agreement theory, this agreement has fulfilled the legal requirements of an agreement. However, in Article 15 of this agreement paragraph (1) which reads: If PT Puri Permata Mega and/or the West Lombok regency government intend to transfer all or part of their interests and/or shares in PT Indotan Lombok, Pte. Ltd. ("Interests Offered") to third parties, PT Puri 
Permata Mega and/or the West Lombok District Government must first offer the Offered Interests to PT Indotan Lombok, Pte. Ltd by giving written notice that clearly and clearly states the terms and conditions of the offer. The implementation was carried out with evidence that PT Puri Permata Mega had transferred its shares to PT Indotan Lombok, Pte. Ltd. This is evidenced by the agreement of Indotan Lombok, Pte, Ltd and the West Lombok Regency Government. West Lombok Regency Government based on the receipt of notification of changes to the Company's data No. AHU-AH.01.10-09847.

\section{Conclusion}

Circular transfer of shares is clearly stipulated in article 91 of Law 40 of 2007 concerning Limited Liability Companies. That decisions outside the General Meeting of Shareholders that are agreed upon by all shareholders are a "binding" decision. That is, the decision has the same legal force as the decisions of the General Meeting of Shareholders conducted physically and conventionally. Then the next arrangement is regulated in Article 14 of the Cooperation Agreement between PT Indotan Lombok Barat Bangkit, Pte. Ltd., PT Puri Permata Mega, and the West Lombok Regency Government. If in the analysis of the theory of the agreement, the implementation of the transfer of these shares has met the legal requirements of an agreement. However, in Article 15 of this agreement paragraph (1) which reads: If PT Puri Permata Mega and / or the West Lombok Regency Government intend to transfer all or part of their interests and / or shares in PT Indotan Lombok Barat Bangkit to third parties, then PT Puri Permata Mega and / or the West Lombok District Government must first offer the Offered Interest Transfer to PT Indotan Lombok Barat Bangkit by giving written notice stating clearly and clearly the terms and conditions of the offer.

\section{References}

Book

Ahmad Yani dan Gunawan Widjaja. (2000). Seri Hukum Bisnis PerseroanTerbatas: Cetakan I, Jakarta, Raja grafindo Persada.

Kurniawan. (2014). Hukum dan Hukum Perusahaan Karakteristik Badan Usaha Berbadan Tidak Berbadan Hukum Di Indonesia: Cetakan I, Jakarta, PT Raja Grafindo.

Ridwan Khairandy. (2014). Hukum Perseroan Terbatas: Cetakan I,Yogyakarta,FH UII Press.

Zaeni Asyhadi dan Budi Sutrisno. (2013). Hukum Perusahaan dan kepailitan: Jakarta: Erlangga.

Azizah. (2015). Hukum Perseroan Terbatas: Malang,Intimedia.

Kurniawan. (2014). Hukum Perusahaan: Yogyakarta, Genta Publishing.

M. Yahya Harahap. (2009). Hukum Perseroan Terbatas: Jakarta,Sinar Grafika.

Chatamarrasjid.(2004). Penerobosan Cadar Perseroan dan Soal-soal Aktual Hukum Perusahaan: Jakarta, PT. Citra Aditya Bakti.

Ridwan Khairandy. (2009). Perseroan Terbatas: Doktrin, Peraturan Perundang-Undangan, dan Yurispruden: Yogyakarta, Total Media Yogyakarta.

Journal Article

Livia Cenggana. (2016). Pengambilan Keputusan Dengan Metode Circural Resolutian Dalam Perseroan 
Terbatas Sebagai Badan Hukum,Jurnal Hukum, vol. 16 No 1, hlm. 9.

Pahlefi. (2016). Eksistensi RUPS sebagai Organ Perseroan Terkait Dengan Pasal 91 Undang-Undang Perseroan Terbatas, Jurnal Ilmu Hukum, vol. 7, No. 2, hlm. 3.

David. (2013). Legalitas Akte Notaris Rapat Umum Pemegang Saham Melalui Media Telekonferensi, Jurnal Ilmu Hukum, vol. 13, No. 1, hlm. 3.

Wardani Rizkianti. (2016). Akte Otentik Rapat Umum Pemegang Saham (RUPS) Melalui Media Telekonferensi (Mekanisme Pembuatan dan Kekuatan Pembuktiannya), Jurnal Yuridis, Vol. 3, No. 1, hlm. 2.

\section{Copyrights}

Copyright for this article is retained by the author(s), with first publication rights granted to the journal.

This is an open-access article distributed under the terms and conditions of the Creative Commons Attribution license (http://creativecommons.org/licenses/by/4.0/). 